\title{
Professional Development of Indonesian Librarians: towards Digital Library Environment
}

\author{
Zulfikar Zen \\ University of Indonesia, Indonesia \\ E-mail: zulfikar_zen@gmail.com \\ DOI: http://dx.doi.org/10.15548/jt.v21i2.91
}

\begin{abstract}
Libraries are an information institution. Nowadays, the information are available in printed, recorded, and online formats. The librarians have to adapt themselves with the latest development, especially with the digital environment. Some libraries in Indonesia have been provided with digital formats such as ebooks, e-journals, and other internet facilities. The library institutions, library schools, and library professional associations in Indonesia have also been involved with the digital environment, resulting in the improvement of their knowledge and skills.
\end{abstract}

Keywords: digital library, librarians, library schools, Indonesian librarians

\section{INTRODUCTION}

The rapid developments of technology in the information era, particularly in the era of telecommunications, multimedia, and digital technologies, have significantly changed the way of librarians generate, collect, organize, present, disseminate, share and use information (Chowdhury, 2004) . Nowadays, the collection of libraries are not only based on the printed materials, multimedia, but also in the digital formats. There are advantages and disadvantages of both formats. The advantages of digital collections are:

1. No physical boundary. The user of a digital library need not to go to the library physically; people from all over the world can gain access to the same information, as long as an Internet connection is available.

2. Round the clock availability A major advantage of digital libraries is that people can gain access $24 / 7$ to the information.

3. Multiple access. The same resources can be used simultaneously by a number of institutions and patrons.

4. Information retrieval. The user is able to use any search term (word, phrase, title, name, subject) to search the entire collection. Digital libraries can provide very user-friendly interfaces, giving clickable access to its resources.

5. Preservation and conservation. Digitization is not a long-term preservation solution for physical collections, but does succeed in providing access copies for materials that would otherwise fall to degradation from repeated use.

6. Space. Whereas traditional libraries are limited by storage space, digital libraries have the potential to store much more information, simply because digital information requires very little physical space to contain them and media storage technologies are more affordable than ever before.

Whereas the disadvantages of digital collection are;

1. Copy right law. It is easy to download and the commercial publishers and writers will loss their benefits.

2. Infrastructure, The digital collections require the infrastructure, such as computer, telecommunication, network, electricity.

3. ICT skills. The users must have the skills to use the ICT and computer facilities. 
4. Expensive. In some extents the digital collections are expensive.

5. Plagiarism. It is easy to do plagiarism of digital collection contents.

6. Less pleasant. Compare to the printed materials, the digital collections are less pleasant for reading.

In order to provide the excellent services, the library must have their collection in various formats, including digital forms. We are living in the digital era with the digital generation as well. The librarians have to take the benefits and avoid the weaknesses of digital resources. In the developing countries such as in ASEAN countries, except Singapore, the digital library application are still being developed. It begins with the use of information communication technology (ICT) for library automation and then introduce digital library services. To be professionals, librarians have to develop their knowledge and the skills.

In this paper I would like to discuss the activities of libraries, library schools and professional organization in dealing with their professional development toward digital library environment.. The result of Conferences of Indonesian Digital Library will also be discussed. .

\section{LIBRARIES IN INDONESIA}

There are about $\mathbf{2 5 1 . 4 4 8}$ libraries in Indonesia with only $\mathbf{3 . 0 8 6}(0,12 \%)$ are functional librarians (Database oof National Library Republic Indonesia, 2013. Functional librarians are registered librarians at the NLRI, and the majority of them are civil servants The rest of library staff are structural and administrative function. The details as shown at the table below.
Table 1: Libraries and Librarians in Indonesia

\begin{tabular}{|c|c|c|c|}
\hline No & Institutions & $\begin{array}{c}\begin{array}{c}\text { Number } \\
\text { of } \\
\text { Libraries }\end{array} \\
\end{array}$ & $\begin{array}{l}\text { Functional } \\
\text { Librarians }\end{array}$ \\
\hline 1 & $\begin{array}{l}\text { National } \\
\text { Library }\end{array}$ & 1 & 181 \\
\hline 2 & $\begin{array}{l}\text { Provincial } \\
\text { Libraries }\end{array}$ & 33 & 711 \\
\hline 3 & $\begin{array}{l}\text { Academic } \\
\text { Libraries }\end{array}$ & 3.226 & 1.395 \\
\hline 4 & $\begin{array}{l}\text { Special } \\
\text { Libraries }\end{array}$ & 1.802 & 496 \\
\hline 5 & $\begin{array}{l}\text { Public } \\
\text { Libraries } \\
\text { (District/City } \\
\text { Libraries) }\end{array}$ & 466 & 129 \\
\hline 6 & $\begin{array}{l}\text { School } \\
\text { Libraries }\end{array}$ & 226.640 & 174 \\
\hline \multirow[t]{2}{*}{7} & $\begin{array}{l}\text { Community } \\
\text { libraries/ } \\
\text { Village } \\
\text { Libraries. }\end{array}$ & 19.280 & \\
\hline & Total & 251.448 & 3.086 \\
\hline
\end{tabular}

The main problem in Indonesia is the availability of qualified and professional librarians. The majority of librarians do not have formal education and information science (LIS) background. According to the rules, to be recognized as a librarians, one must have at least Diploma II (D2) certificate in LIS.

\section{National Library}

National Library of Republic of Indonesia (NLRI) was established on May 17, 1980. The conventional collection are about 1,565.065 volumes, the digital collection are about 34.177 title e-journals, and 13.009 ebooks. There are about 729 library personnel, and $24,38 \%$ are librarians The main function of NLRI is the same with other national library in the world, but NLRI has another function such as fostering all aspect of library developments, including the professional development.. 
NLRI have implemented the ICT in its management and services. Its collections are not only on printed and multimedia forms but also in digital forms,. Since early 2000, NLRI have digitalized its special library collection, especially on Indonesian cultural heritages collections. Since 2008 NLRI has a project call as the National Digital Library Planning (NDLP). The purposes of NLDP are:

1. To Improve access of information resources and services that are available among library networking members (resource sharing).

2. To promote of inter-cultural understanding and awareness within the national scope; providing learning resources; encourage the availability of library materials and information that contains the value of the local culture (local content)

3. To preserve of the information resources on Indonesia.

4. To support of scientific research through the utilization of the internet

NLRI supported the first Conference of Indonesian Digital Library (CIDL) on Desember 2, 2008, in Kuta Bali, since then the conference was conducting every year.

\section{Academic Libraries}

There are about 3226 higher education in Indonesia and $3144(97,6 \%)$ are privates, and $82(2,54 \%)$ are states institutions. (3068). Interm of quantity, almost all of them have library. The academic library's potential users are 3.205.862 students and 395.826 lecturers. The library is one of the basic assessment by the National Accreditation Board of Higher Education (BAN PT). In general, academic libraries are leading more than the other libraries in application of ICT in their activities. Beside the conventional collection, the academic libraries also have the digital collection. The local publications such student's final works (skripsi, thesis, dissertation), research papers, etc are submitted to the library in digital format (born-digital).
With the support of the Directorate of Higher Education, Department of National Education Republic Indonesia (DNERI) and Indonesian Academic Library Forum (FPPTI) have launched "Garuda Portal" web site. The portal is one of the result of networking among academic libraries on digital activities. The academic libraries, especially state academic libraries have the potential asset on digital resources. Those libraries are providing the digital collection, such as e-books, e-journal and maintain e-databases to serve their users.

The main problems at the academic libraries is the availability of qualified librarians. The majority of academic libraries are managed by non professional librarians. Fortunately, the Forum of Indonesian Academic Library is the most active organization in conducting the non formal education to its members.

\section{School Libraries}

Data at the NLRI in 2013 states that there are about 226.640 School Libraries. According to the Ministry of National Education Rules No. 23 Year 2007 every school have to have a library. Standard minimum of a school library collection is 1000 titles. The collection consist of text books, enrichment resources, reference resources, , multi media, etc. The Department National Education Republic of Indonesia provides textbooks in 3 (three) formats, they are printed, recorded on $C D$ and digital version (online). Almost all of text books for Elementary School, Junior High Schools and Senior High School are available in digital format. Board of Education National Standard publish text book collections freely, and will not be revised in 5 years.

Due to many of schools are in the village or remote area, the digital collection cannot be accessed because of the limited infrastructure, such as electricity, computer and communication facilities. Besides, the teaching system, such as face to face approach in classroom is still dominant at schools. The main 
problem of school libraries are facing the availability of professional librarians. The majority of school libraries are operated by teacher or administrative staff. Short courses or trainings are the only way to improve knowledge and skill of teacher or administrative staff.

\section{Public Libraries}

There are two types of Public Library in Indonesia. Firstly, Public Libraries which are directed and financed by the government. There are 33 Provincial Libraries, and 457 District Libraries. In order to extend their services, public library are also providing mobile library and floating library.

Secondly, Community Libraries which are founded and financed by the community. Sometimes they do not call themselves as a library but as Community Reading Garden (Taman Bacaan Masyarakat), Book Café, Reading House (Rumah Baca). Clever Car or Clever Motorcycle (Mobil Pintar or Motor Pintar). The villages libraries (Perpustakaan Desa, Kelurahan, Nagari) are also treated as community libraries. there are about 19.280 communities libraries Based on experiences and observation, the existence of community library are not in a long period.. The community library depends on the founder and sponsor. As we know that the library without finance, soon or later will be closed or die slowly.

The majority of public libraries are facing problem with the human resources and financial support. Approximately $90 \%$ of general public have no professional librarians. Some of the decision makers are thinking that the librarians are as "book custodians" or "book keepers". The professional development for library staff at public libraries through non formal education are such a short course, training and internships in the limited time. The content of the training or courses also include introduction to application of ICT in library.

The internet services have already been available in the public library. The majority of collection are available in printed forms. The digital collections are only available in Provincial Library and in some District Library. There are many activities that should be done for the public library. The local government should be convinced that the library staff should be trained and the user communities should be promoted on the digital library collection and services, furthermore, the ICT facilities should be maintained.

\section{Special Libraries}

There are about 1.802 special libraries in the year 2013 and 496 functional librarians. The main objective of special libraries is to support the researchers, decision makers and administrators .where the libraries are belong to. The majority of special libraries collections and services are still based on conventional condition. Some of them are already introduced and collected in digital forms. In many cases, the researcher tend to use more digital format or online access than the conventional format one.

The roles of special librarians are as integral part in the organization. The librarians have to adapt their activities to the objectives of institution are belong to.. The recognition of special library depend on the librarians performances. The special library at the government offices are still limited, both quality and quantity. Many of library staff have no library and information science background. The library facilities, included the ICT facilities are very poor. The impact of democratic euphoria, the government do not yet provide the special library as an important position to improve the staff performance.

Professional development of special librarians are providing non formal education, such as training, workshop, internship on librarianship, The subject of non-formal education includes the implementation of ICT in the library. 


\section{LIBRARY EDUCATIONS IN INDONESIA}

There are three types of education in Indonesia, formal, non formal and informal education. The formal educations are the education from elementary schools to higher education (universities). The non formal educations are such as training, internship, fieldwork, etc. The informal educations are self education, family education, reading, etc. In this chapter, I would like only to present more on the formal education for librarians.

The formal education for librarians in Indonesia is conducted at the higher education level. Under the Higher Education Act No. 12, year 2012 on Higher Education, the education system at Higher Education (university level) consists of two program. They are Academic Education System (AES) and Vocational Education System (VES). The main difference between two education systems is not only the number of credits required, but also the learning and teaching approach. The Academic Education System is more on theoretical approach while the Vocational Education System is more on practical approach. At the present (2014), Indonesia has 32 library and information science (LIS) schools. The are 6 Master Programs, 22 Undergraduate Programs and 22 Diploma Programs.

In the year of seventies and eighties, "the library automation" is one of the popular courses at LIS schools. The content of courses are introduction to computer science and the application of software for library activities (acquisition, cataloguing, circulation, etc). In order to help the developing countries, Unesco provides CDS-ISIS software for library application.

In order to prepare the qualified librarian and to anticipate the future development toward the digital environment, the ICT courses is compulsory at the DLIS. The ICT courses consist of:

- Introduction to Library Automation
- Introduction to Information and Communication Technology,

- Introduction to Computer Science / Basics information Technology,

- Data Bases Management

- Database for Information Institutions

- APPLICATION Information Technology

- Digital Library Management

- ELECTRONIC Records and Archives

- Multimedia Technology

- Information Literacy

In some cases, others courses such as Basics References, Information Literacy, etc also use online searching and digital resources collections. Before finishing their study, students must have a two months practical field work in the advance library and information centers. Usually LIS schools have ICT laboratory to support the curricula and to have the practical experiences.

\section{PROFESSIONAL ORGANIZATIONS}

Indonesian Library Association (ILA) established at July 6, 1973 is one of a professional organization of Indonesian librarians. The objective of ILA in its constitution (1973) was :

a) To facilitate the librarians inspiration and creation

b) To improve the librarians image

c) To provide the service to the community

d) To improve library science

Every three years ILA conducts the National Congress. The purposes of congress are to elect the new President, to plan the program and to adapt the constitution and code of ethics with the latest development. After 40 years, ILA Congress 2013 was held in Palembang, the objective of association was stated in the constitutions :

a) Improving professionalism of Indonesian librarians,

b) Developing of Library and information science 
c) Using the librarians expertise to serve the nation and the state.

It is clear that the "professional development" of ILA members is one of the most important objective. Many activities of professional developments are provided for ILA members. They are non-formal educations, such as training, publishing, seminars. "Marsela" and "Majalah Ikatan Pustakawan Indonesia" are journals to facilitate scientific communication among librarians and to improve knowledge and skill of ILA members. ILA and its member are also involved with the professional organization at the regional and international level, such as in CONSAL, IFLA, COMLIS, etc.

After the reform era (1998), Indonesia was introduced to the real democratic system. In New Orde Era, ILA is the only one professional organization for librarians. After the reform era, the new organization for librarians was set up. They are:

1. Forum of Indonesian Academic Library (FPPTI), 12 October 2000.

2. Forum of Indonesian Special Library (FPKI), 18 November 2000.

3. Forum of Indonesian Public Library (FPUI), 4 June 2002.

4. Forum of Indonesian School Library, (FPSI), 8 August 2002.

5. Community Reading Habit Movement (GPMB), 25 October 2001.

6. Association of Indonesian Library and Information Science Scholar (ISIPII), 23 March 2006.

7. Association of Indonesia Information Workers (APISI), 26 August 2006-

8. Association of Indonesian School Library Professional (ATPUSI), 28 May 2009.

9. Association of Indonesian Library Schools (APPIPII), 17 September 2012.

10. Association of Indonesian Islam Academic Library (APPTAII), 2013.

The main objective of those associations is to improve the library service and to develop knowledge and skills of their members.. The professional development is by providing and conducting the non formal education, such as training, internship, workshop, seminars, field study, comparative study, etc. The subject of digital library environment is one the priority of their activities. Nowadays, almost all librarians are facing the digital library environment. Although in the limited number, all kind libraries in Indonesia already have their collection in digital formats. In order to improve the library service the availability of digital format is a need and the qualified and skilled librarian is a must..

\section{CONFERENCE OF INDONESIAN DIGITAL LIBRARY}

As explained before, the NLRI and many others libraries who have the digital collection and services or involve with digital library development have come to the agreement to have the conference on digital library, namely Conference of Indonesian Digital Library/ CIDL (Konferensi Perpustakaan Digital Indonesial (KPDI). The first CDIL was conducted at 2 December 2008 in Kuta Bali. The outputs of conference are 7 declarations and 5 recommendation. The declaration are:

1. Accepting and following the Library Act No. 43 year 2007 on library.

2. Optimal of using available Information Communication and Technology investment

3. Information resource sharing among institutions and information exchange between the rich and the poor of information

4. Developing digital content for mutual benefit among members

5. Accessibility of digital library to use the information resources among the members

6. Providing the continuing education and training for library human resources to improve their knowledge and skill to anticipate the environment change, especially in ICT

7. Conducting the Conference of Indonesian Digital Library at every year to share experiences, knowledge and result of research in order to develop digital library in Indonesia 
It is clear that the training of human resources is very important to have knowledge and skills in order anticipate the fast development of environment, especially the change of ICT for library, and digital library as well.

The recommendation to the government are;

1. Government have to provide clear career of library staff

2. Government have to provide budget for maintenance and operation of digital library

3. Government have to provide budget for development of digital content and application of Digital Library

4. infrastructure of computer and communication network to facilitate the cooperation and use information resources.

5. The government have to synchronize all initiative at all the government institutions in acquisition and using resources that dealing with digital library development, especially on ICT resources.

The involvement of government in digital library development is a must. It is impossible to develop the digital library without stated policy and finance support. NLRI as fostering institution supports by conducts the conference every year. Six conferences have been done and the latest was in Malang, Eats Java, in 2013.. The stakeholders of digital library were invited, e.g, computer and communication science expert, scientists, decision makers, library users, and librarians. During the conferences, hundreds of papers were presented. The speakers were not only from Indonesia but also from foreing countries.

\section{CONCLUSION}

There are 3 (three) institutions which are involved in professional development toward the digital library environment, in Indonesia. They are; a). Library institutions have developed their collection and services based on digital resources; b). Library schools have developed their curricula to ICT and digital environment; c).. Library professional organizations have also provided the non formal education toward digital library environment for their members.

Due to the fast developments of information communication and technology particularly in digital technologies, the sharing of knowledge and the exchanging of experiences must be maintenance by regular communication and continuing professional development.

Finally, Building a positive attitude of librarians in digital library environment is a must. It is also necessary to establish trust, recognition and respect to each other among librarians. The intent of cooperation, is to share of the strengths not to avoid the weaknesses

\section{REFERENCES}

Allan, Barbara. E-learning and teaching in library and information services.London: Facet Publishing, 2002

Anna, William Y. Digital libraries.Cambridge: MIT, 2000

Chowdhury, G.G. Introduction to modern information retrieval.--London: LA Publishing, 2004

Greenstein, Daniel. "Digital libraries and their challenges" in Library Trends 49 (2): 290303

Ikatan Pustakawan Indonesia. Anggaran Dasar / Anggaran Rumah Tangga dan Kode Etik.—Jakarta : IPI, 2013

Pendit, Putu Laxman, dkk. Perpustakaan digital: perspektif Perpustakaan Perguruan Tinggi Indonesia.-_Jakarta: Sagung Seto dan Universitas Indonesia, 2007 
Prosiding Konferensi Perpustakaan Digital Indonesia (KPDI) ke-2, --Jakarta: Perpustakaan Nasional RI, 2009

Raitt, David. Libraries for the new millennium.- London : LA Publishing, 1997

Rowley, Jennifer. The electronic library.London: Facet Publishing, 1998

Tedd, Lucy A. and Andrew Large. Digital libraries : principles and practices in a global environment. -Munchen: K.G. Saur, 2004
Zen, Zulfikar Indonesian Library Associations: a country report.-- Iakarta Indonesian Library Association, 2104

Zen, Zulfikar "Library and Information Science Education in Indonesia" paper presented at The Seminar on Library and Information Science Education Collaboration among ASEAN Countries Hosted by Sukhothai Thammathirat Open University Bangkok, 14-16 July 2013

Zen, Zulfikar. Library and Information Science Educations in Southeast Asia. Jakarta: Indonesian Library Association, 2104 